\title{
Cutaneous Amyloidoma: A Rare Case Report
}

\author{
Demet Kartal, Özlem Canöz ${ }^{1}$, Süleyman Balkanlı ${ }^{1}$, S Levent Çınar, Ayten Kesikoğlu, Murat Borlu \\ Departments of Dermatology and Venereology and ${ }^{1}$ Pathology, Erciyes University Faculty of Medicine, Kayseri, Turkey
}

\begin{abstract}
Dear Editor:
Amyloidosis comprises a group of diseases characterized by extracellular deposition of unique insoluble, fibrillar, proteinaceous material. On light microscopic examination, amyloid appears as an eosinophilic amorphous hyaline extracellular substance, which turns green-yellow after Congo-Red staining and examination under polarized light. Amyloidoma is defined as primary solitary amyloidosis in which no plasma-cell dyscrasia or abnormal serum proteins are detectable. We here in report an unusual case of skin amyloidoma.
\end{abstract}

A 65-year-old woman presented to Erciyes Universtiy Medical Faculty Dermatology Department Outpatient Clinic with two masses located on the right chest under the mammarian area. The lesions had grown in size over the past 5 years. The lesion had become ulcerated over the last month. Two biopsies had been performed previously ( 1 year and three years ago). Both of them were reported as squamous epitheliomatous hyperplasia. She had been diagnosed as having Sjögren syndrome 11 years ago. On examination there were two skin-colored firm nodules with a smooth surface, one of them had a hemorrhagic border and the other was ulcerated. Their measurements were found as approximately $2 \times 2.5 \mathrm{~cm}$ and $3 \times 3 \mathrm{~cm}$ (Fig. 1). Histologic examination revealed homogenization of the dermal connective tissue with deposits of amorphous material (Fig. 2A, B). Extensive amyloid deposits in the entire dermis were positive with Congo-red staining (Fig. 2C) with the character-

Received June 4, 2015, Revised July 14, 2015, Accepted for publication August 25, 2015

Corresponding author: Demet Kartal, Department of Dermatology and Venereology, Erciyes University Faculty of Medicine, Erciyes Üniversitesi Tip Fakültesi Deramatoloji AD, Talas Kayseri 38039, Turkey. Tel: 90352-2076666, Fax: 90-352-4377615, E-mail: demetkartal@hotmail.com

This is an Open Access article distributed under the terms of the Creative Commons Attribution Non-Commercial License (http://creativecommons. org/licenses/by-nc/4.0) which permits unrestricted non-commercial use, distribution, and reproduction in any medium, provided the original work is properly cited.

Copyright $($ c The Korean Dermatological Association and The Korean Society for Investigative Dermatology istic apple-green birefringence under polarized light. The amyloid type was determined immunohistochemically as AA (secondary) amyloid (clone mc1; Dako) (Fig. 2D).

The patient underwent further investigations for systemic amyloidosis. Axial computed tomography scan at the lung window shows cluster of multiple small nodules in the right lower lobe and at the soft tissue window showed skin lesion were suggestive of amyloidosis (Fig. 2E, F). Echocardiography, ultrasound of the abdomen, pelvis and lymph nodes of the neck, axilla and groin showed no signs of systemic amyloidosis. Blood analyses including immunoglobulins and immunoelectrophoresis were unremarkable. The patient was consultated with the pulmonary medicine department. The patient is currently being followed up for systemic amyloidosis.

Amyloidoma is defined as primary solitary amyloidosis ${ }^{1}$. It has been described in widely varied anatomic sites including the genitourinary tract, breast, respiratory tract, nasal sinuses, mediastinum, gastrointestinal tract, retroperitoneum, mesentery, eye, bone and joints, lymph node, spleen and parotid gland. Amyloidoma of the skin is a very rare con-

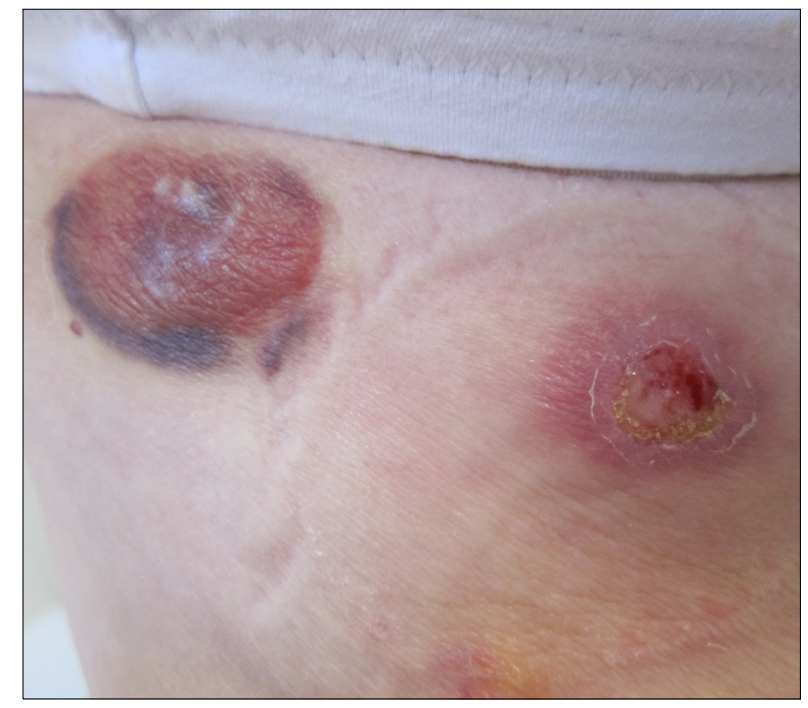

Fig. 1. Two skin-colored firm nodules with a smooth surface, one of them had a hemoragic border and the other was ulcerated. 

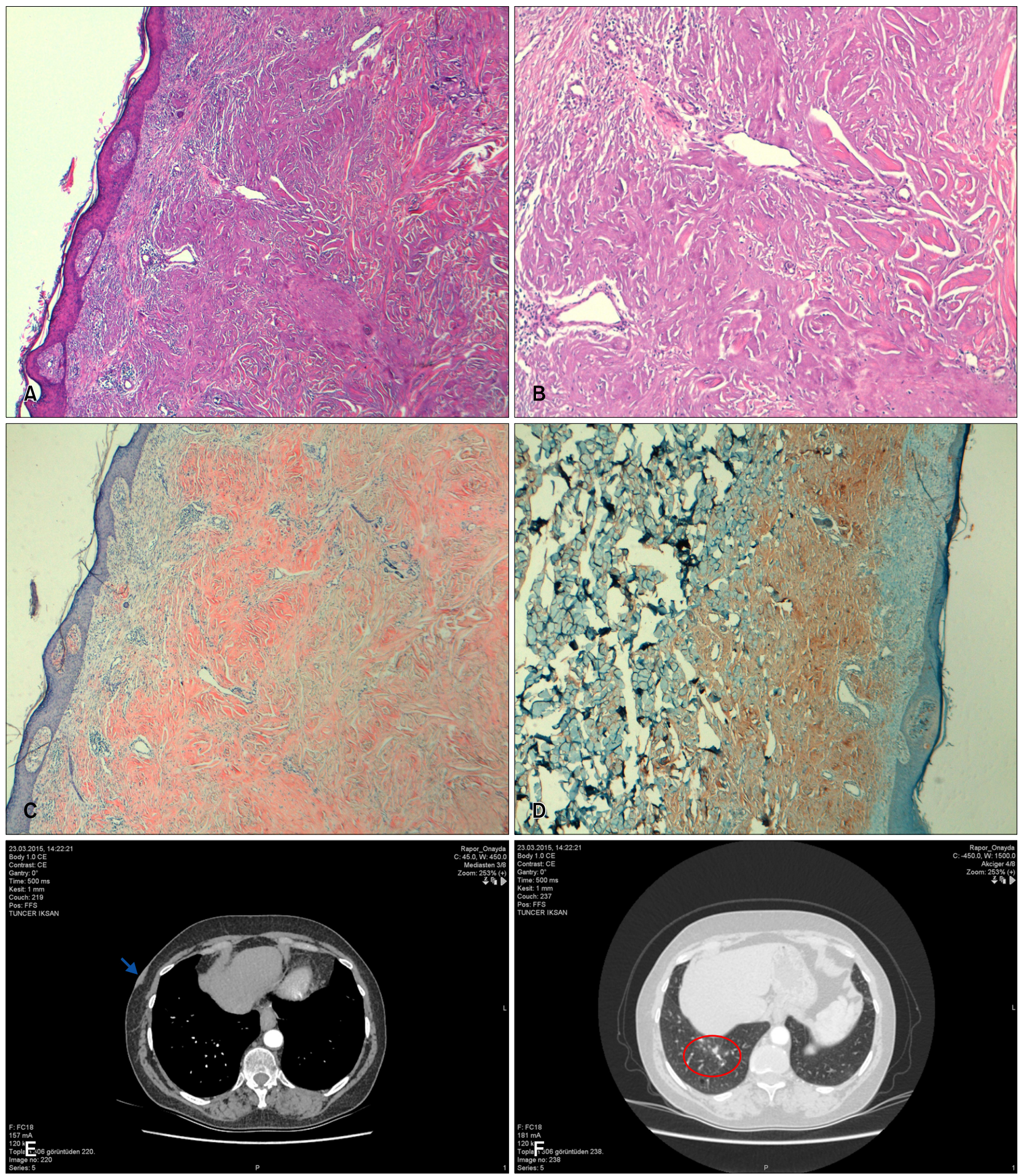

Fig. 2. (A, B) Dermal connective tissue with deposits of amorphous material (H\&E). (C) Extensive amyloid deposits in the entire dermis were positive with Congo-red staining. (D) The amyloid type was determined immunohistochemically as AA amyloid. (E) Axial computed tomography (CT) scan at the soft tissue window shows skin lesion (arrow). (F) Axial CT scan at the lung window shows cluster of multiple small nodules in the right lower lobe (circle).

dition, and only a few cases have been described in the literature so $\mathrm{far}^{2,3}$. We determined the AA type of amyloidosis. Sjögren syndrome was described with paranasal ${ }^{4}$ and pulmonary amyloidoma ${ }^{5}$ previously to the best of our knowledge AA type skin amyloidoma with Sjögren syndrome and with pulmonary involvement has not been re- 
ported before in the literature. We believe that amyloidoma might have been presented as a complication of Sjögren syndrome in this patient. Although local resection is curative for amyloidoma, patients must be evaluated for systemic involvement of amylodosis.

\section{REFERENCES}

1. Bauer WH, Kuzma JF. Solitary tumors of atypical amyloid (paramyloid). Am J Clin Pathol 1949;19:1097-1112.

2. Reitboeck JG, Feldmann R, Loader D, Breier F, Steiner A.
Primary cutaneous amyloidoma: a case report. Case Rep Dermatol 2014;6:264-267.

3. Biewend ML, Menke DM, Calamia KT. The spectrum of localized amyloidosis: a case series of 20 patients and review of the literature. Amyloid 2006;13:135-142.

4. Banno S, Matsumoto Y, Hayami Y, Sugiura Y, Yoshinouchi T, Ueda R. Pulmonary AL amyloidosis in a patient with primary Sjögren syndrome. Mod Rheumatol 2002;12:84-88.

5. Mlika M, Ayadi-Kaddour A, Marghli A, Ridène I, Maalej S, EI Mezni F. A rare pulmonary lesion association. Rev Pneumol Clin 2012;68:303-306.

\title{
A Case of the Migration of Hyaluronic Acid Filler from Nose to Forehead Occurring as Two Sequential Soft Lumps
}

\author{
Soo Yuhl Chae, Kyou Chae Lee, Yong Hyun Jang, Seok-Jong Lee, Do Won Kim, Weon Ju Lee \\ Department of Dermatology, Kyungpook National University School of Medicine, Daegu, Korea
}

\section{Dear Editor:}

Hyaluronic acid (HA) fillers have been widely used for soft-tissue augmentation. Because of HA's biocompatibility and biodegradability, adverse reactions are minimal. However, HA-related complications, such as delayed foreign body granulomas, delayed hypersensitivity, and necrosis have been reported $^{1,2}$. We herein present a case of 2 sequential soft facial lumps after injection of a $\mathrm{HA}$ filler. A 33-year-old woman presented with a bean-sized, fleshcolored, soft, movable, subcutaneous mass on her forehead that had been present for 3 months (Fig. 1A). Sixteen months ago, she had been injected with a HA filler (YVOIRE $^{\mathbb{R}}$; LG Life Sciences, Seoul, Korea) on her nose at a private clinic. She had not undergone any filler injection on the forehead. Clinically, the patient was assessed to have an angioma or lipoma and underwent surgical excision of the mass after injection of a local anesthetic agent. Histopathological examination showed the presence of irregular, amorphous, light grayish to bluish material that separated from dispersed collagen bundles with sparse inflammatory cell infiltration in the lower dermis and subcutaneous fat (Fig. 1B, C). The amorphous material stained blue with Alcian blue, $\mathrm{pH} 2.5$ (Fig. 1D). These findings were considered to be consistent with HA. Two weeks after the excision, another, bean-sized, flesh-colored, soft, movable subcutaneous mass was found on the patient's glabella. Surgical removal was also performed, and histologic findings were the same as for the previous

Received July 1, 2015, Revised August 5, 2015, Accepted for publication September 1, 2015

Corresponding author: Weon Ju Lee, Department of Dermatology, Kyungpook National University Hospital, 130 Dongdeok-ro, Jung-gu, Daegu 41944, Korea. Tel: 82-53-420-5838, Fax: 82-53-426-0770, E-mail: weonju@knu.ac.kr

This is an Open Access article distributed under the terms of the Creative Commons Attribution Non-Commercial License (http://creativecommons.org/ licenses/by-nc/4.0) which permits unrestricted non-commercial use, distribution, and reproduction in any medium, provided the original work is properly cited.

Copyright (C) The Korean Dermatological Association and The Korean Society for Investigative Dermatology 